九州大学学術情報リポジトリ

Kyushu University Institutional Repository

Trials for Rapid Identification of

Phytopathogenic Bacteria by HPLC and the Direct Colony TLC

Matsuyama, Nobuaki

Laboratory of Plant Pathology, Faculty of Agriculture, Kyushu University

https://doi.org/10.5109/24096

出版情報: 九州大学大学院農学研究院紀要. 40 (1/2)，pp.87-91，1995-12. Kyushu University バージョン：

権利関係 : 


\title{
Trials for Rapid Identification of Phytopathogenic Bacteria by HPLC and the Direct Colony TLC
}

\author{
Nobuaki Matsuyama \\ Laboratory of Plant Pathology, Faculty of Agriculture, \\ Kyushu University, Fukuoka 812-81, Japan \\ (Received July 17,1995)
}

\begin{abstract}
A novel technique with HPLC for rapid identification of phytopathogenic bacteria was devised and its usefulness was estimated comparing with the direct colony TLC. One loopful bacteria was suspended in $0.5 \mathrm{ml}$ of chloroform-methanol $(2: 1, \mathrm{v} / \mathrm{v})$ in a small glass-vial and kept for $1 \mathrm{hr}$ in room temperature. After the evaporation of the solvent, $1 \mathrm{ml}$ of $\mathrm{SO} \%$ aqueous methanol solution was added and the extract was dissolved. This solution was passed through a membrane filter and $20 \mathrm{\mu l}$ of it was subjected to HPLC. The diversity of chromatograms obtained for two genera of bacteria, Clavibacter and Eruinia, was quite obvious and the distinct differences were also observed at species level in Eruinia.
\end{abstract}

\section{INTRODUCTION}

The identification of phytopathogenic bacteria has been conducted by morphological, physiological, serological and pathological tests. These tests, however, are timeconsuming and need experiences for analyzing results. In 1986, the direct colony thin layer chromatography was invented (Matsuyama et al., 1986) and firstly applied for rapid identification of phytopathogenic bacteria (Matsuyama 1993a, Matsuyama et al., 1993b, c, d, Matsuyama and Furuya, 1993e). In these experiments, it was clarified that the differentiation of the phytopathogenic bacteria at generic level was available among Clavibacter, Agrobacterium and others. Further, in genus Erwinia, the profiles of E. chrysanthemi and E. carotovora subsp. carotovora were clearly different. Such differences at species level were also observed among some species of genus Pseudomonas. These results indicated practical usefulness of this easy method for rapid identification of phytopathogenic bacteria. In the case of identification at subspecies or pathovar level, however, higher resolution ability in chromatography will be required. Therefore, the introduction of HPLC technique and invention of a novel procedure for more rapid and reliable identification of bacteria was conducted.

\section{MATERIALS AND METHODS}

\section{Phytopathogenic bacteria used}

Clavibacter michiganensis subsp. michiganensis (N6601, N6204, N6206, N6207, 5215), C. m. subsp. sepedonicus (I), Erwinia carotovora subsp. carotovora (473-1, 493-1, EH8519), E. chrysanthemi pv. chrysanthemi (Ichihara 1-1, Ku8601,E8301),E.

This study was supported in part by the Grant-in-aid from the Ministry of Education,Science and Culture of Japan (No. 06454064). 
ch. pv. dianthicola (Dianthi le, Dianthi 2n Sl) E.ch. pv. zeae (ALE8292p, NCPPB 377', R7, R8) were used in this experiment. Details of each isolate have been presented in the former reports (Kori et al., 1992, Matsuyama et al., 1993b, c, d, Matsuyama and Furuya, 1993e).

\section{Culture}

Each bacterial strain was cultured on the slant of King B medium (Eiken Chemical Co.) at $30^{\circ} \mathrm{C}$ for 3 days. The ingredient of the medium was as follows : $20.0 \mathrm{~g}$ Peptone, $1.5 \mathrm{~g} \mathrm{~K}_{2} \mathrm{HPO}_{+}, 1.5 \mathrm{~g} \mathrm{MgSO}_{+} \cdot 7 \mathrm{H}_{2} \mathrm{O}, 15.0 \mathrm{~g}$ agar, 11 of $1 \%$ glycerol solution, $\mathrm{pH}$ 7.2.

\section{Direct colony TLC method}

One loopful bacterial cells was pasted directly on the origin of TLC plate (Merck Co.) and dried completely. This plate was developed with chloroform-methanol $(2: 1, \mathrm{v} / \mathrm{v})$ for $10 \mathrm{~min}$ and dried. After scraping off the bacterial cells, this plate was developed to the same direction with chloroform-methanol-water $(60: 25: 4, \mathrm{v} / \mathrm{v} / \mathrm{v})$. The spots of aminolipids were detected by ninhydrin and photocopied. The details have been presented in other papers (Matsuyama et al., 1993a, b, c, d, Matsuyama and Furuya, 1993e).

\section{Rapid identification method by HPLC}

One loopful bacterial cells was suspended in $0.5 \mathrm{ml}$ of chloroform-methanol $(2: 1$, $\mathrm{v} / \mathrm{v}$ ) in a small glass-vial and capped tightly. Then it was kept for $1 \mathrm{hr}$ in room temperature. After the evaporation of the solvent in a weighing glass-vessel (ca. $3 \mathrm{~cm}$ in diameter), $1 \mathrm{ml}$ of $80 \%$ aqueous methanol solution was added and the extract was dissolved. This solution was passed through a disposable membrane filter tip (Advantec

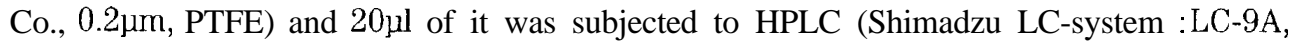
SPD-10A, Chromatopac C-R5A,DGU-10A) equipped with reversed-phase column (Shimpak HRC-ODS). The elution was carried out with $80 \%$ aqueous methanol solution at $1 \mathrm{ml} / \mathrm{min}$ and the detection was conducted at $210 \mathrm{~nm}$.

\section{RESULTS AND DISCUSSION}

As can be seen in Fig.1, the TLC chromatograms of genus Clavibacter, gram positive bacteria and genus Erwinia, gram negative bacteria, were quite different. The spot at $\mathrm{Rf}$ 0.63 which appears in the case of gram negative bacteria was absent in Clavibacter michiganensis subspecies used. This distinct difference was always observed regardless of use of young or aged bacterial cells (Matsuyama et al., 1993c). As reported previously, the chromatograms were different at generic level or sometimes at species level. The benchmark of each genus or species was stable and appeared on TLC chromatogram at high degree of reproducibility. When the benchmarks existed at similar $\mathrm{Rf}$ values, however, their distinction will not be easy. Therefore, the use of other complementary and easy chromatographic procedures has been required.

A novel technique for rapid identification of the phytopathogenic bacteria with HPLC was invented firstly by the author and was contributed in this report. This method 
resembles with the direct colony TLC (Matsuyama et al., 1986, 1987, Matsuyama et al., 1993a, b, c, d, Matsuyama and Furuya, 1993e) in principle. In the TLC method the extraction of lipids was carried out on a silica gel plate. While in this novel method by HPLC, the extraction was conducted in a small glass-vial with chloroform-methanol solution (2: 1, v/v). The extract was dissolved in a small volume of $80 \%$ aqueous methanol solution, subjected to HPLC and eluted with $80 \%$ aqueous methanol solution. The peaks on the chromatograms obtained will represent partly phospholipids from bacterial cells. In this system, the detection of peaks was conducted by UV (210nm) detector, and hence size of each peak will not always reflect the quantity of each lipid.

Distinct differences for HPLC profiles around Rt $2 \mathrm{~min}$ were observed between genera Clavibacter and Erwinia. Further, obvious diversity at species level was also detected

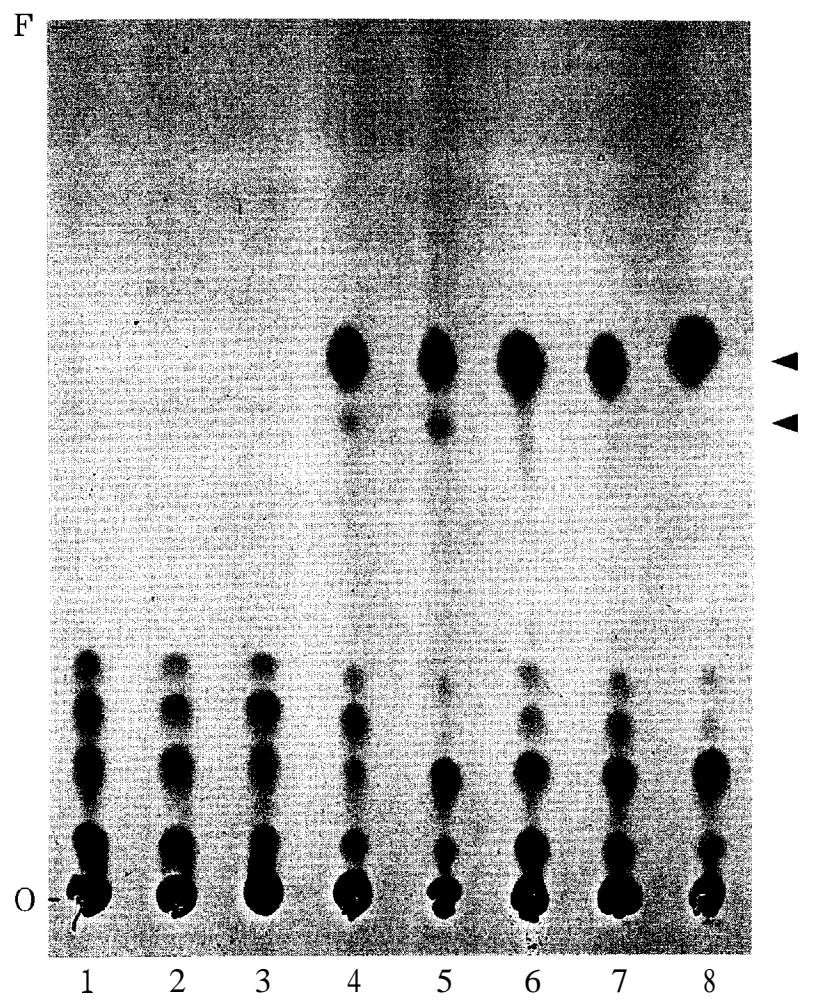

Fig. 1. TLC chromatogram of lipids from phytopathogenic bacteria.

1: Clavibacter michiganensis subsp. michiganensis N6206

2: " " " " " 6204

3: " "sepedonicus I

4: Erwinia carotovoru subsp. carotovoru 493-1

5: " " " 473-1

6: " chrysanthemi pv. chrysanthemi Ichihara 1-1

7: " " " pv. " E8301 L1

8: " " pv. zeae ALE8292p

Arrow heads indicate the benchmarks of Gram-negative bacteria (Rf 0.63) and Erwinia carotovora subsp.carotovora (Rf 0.55). 0 : Origin, F : Front 

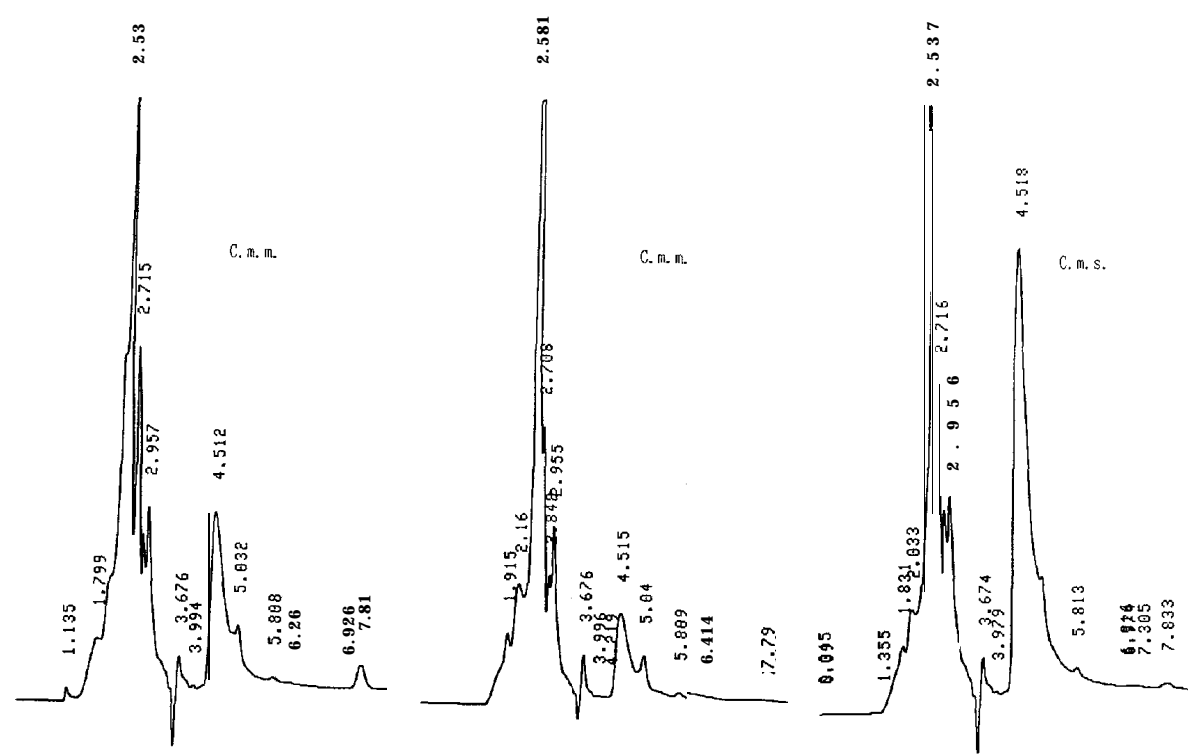

Fig. 2. HPLC chromatograms of Clavibacter michiganensis subspecies.

Left (C. m. m.) : Clavibacter michiganensis subsp. michiganensis $\mathrm{N} 6206$ Center (C. m. m.) : " " " " " N6204 Right (C.m.s.) : " " " sepedonicus I
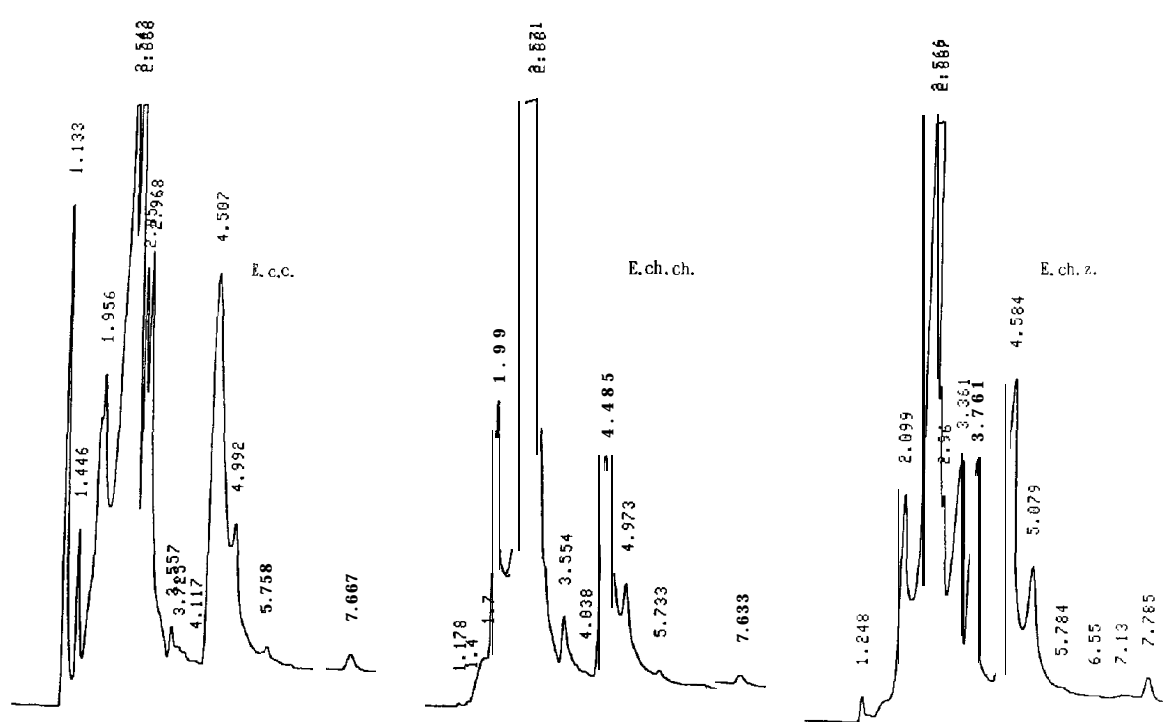

Fig. 3. HPLC chromatograms of Erwinia species.

Left (E. c. c.) : Erwinia carotovora subsp. carotovora 473-1

Center (E. ch. ch.): " chrysanthomi pv. chrysanthemi Ichihara 1-1

Right (E. ch. z.) :

" " pv, zeae ALE8292p 
between Erwinia carotovora subsp. carotovora and $E$. chrysanthemi like TLC chromatogram (Fig. 1, 2, 3). Several peaks appeared prior to Rt 2 min will be benchmarks of $E$. carotovoru subsp. carotovora and these were absent on the chromatogram of $E$. chrysanthemi. Since the correspondence of each peak on HPLC chromatogram and each spot on TLC chromatogram has not been investigated, it is uncertain if the peak at ca. Rt 1.4 min will correspond with the benchmark spot of $E$. carotovora subsp. carotovora at Rf 0.55 (Fig.1). Although rapid identification of bacteria at species level by this HPLC system is available with some exceptions,improvement of the procedures with other kind of columns and solvent systems will be required. This is the subject of future study.

\section{ACKNOWLEDGEMENT}

The author is grateful to Dr. N. Furuya for his kind supply of the phytopathogenic bacteria.

\section{REFERENCES}

Kori, Y., N. Furuya, K. Tsuno and N. Matsuyama 1992 Differentiation of Erwinia chrysanthemi and E. carotovora by the cellular fatty acid analysis. J.Fac. Agn, KyushuUniv., 37(2): 173-178

Matsuyama, N. 1993a Rapid identification of phytopathogenic bacteria by the direct colony thin-layer chromatography. Proc.6th International Congress of Plant Pathology, Montreal, Canada, p. 44

Matsuyama, N., Ismail Hossain Mian, Abdul Mannan Akanda and N. Furuya 1993b Application of the direct colony TLC method for identification of phytopathogenic bacteria. J.Fac. Agr., Kyushu Unim, 37(3,4): 281-285

Matsuyama, N., Ismail Hossain Mian, Abdul Mannan Akanda and N. Furuya 1993c Rapid identification of phytopathogenic bacteria by the direct colony thin-layer chromatography (1). Proc. Assoc. PI. Prot. Kyushu, 39: 60-64

Matsuyama, N., Ismail Hossain Mian, Abdul Mannan Akanda and N. Furuya 1993d. Comparative studies on thin-layer chromatograms of lipids from various phytopathogenic bacteria. Arm. Phytopath. Soc. Japan, 59: 528-534

Matsuyama, N. and N. Furuya 1993e Application of the direct colony TLC for identification of phytopathogenic bacteria (II) Chromatographic profile of Erwinia and Pseudomonas spp. J.Fac. Agr., KyushuUniv., 38(1, 2): 89-95

Matsuyama N. and N. Furuya 1995 Trials of a rapid identification of phytopathogenic bacteria by HPLC I. Use of the reversed-phase column. Ann. Phytopath. Soc.Japan, 61: in press.

Matsuyama, T., M. Sogawa, K. Kaneda and I. Yano 1986 Rapid detection and identification of bacterial lipids by direct colony thin-layer chromatography. Proc. of 23rdinternational symposium of advances in chromatography, Chiba, Japan, pp. 127-128

Matsuyama, T., M. Sogawa and I. Yano 1987 Direct colony thin-layer chromatography and rapid characterization of Serratiamarcescens mutants deffective in production of wetting agents. Appl. Environ. Microbiol, 53: 1186-1188 